Predrag Vuković ${ }^{1}$

Institute of Agricultural Economics, Belgrade

Marija Mosurović Ružičić ${ }^{2}$

Institute „Mihajlo Pupin“ Belgrade
SCIENTIFIC REVIEW ARTICLE doi:10.5937/ekonomika2001077V

Received: January, 18. 2020. Accepted: March, 03. 2020.

\title{
POTENTIALS FOR DEVELOPMENT FOOD TOURISM IN AP VOJVODINA IN THE REPUBLIC OF SERBIA ${ }^{3}$
}

\begin{abstract}
The aim of the paper work is to present the concept of food tourism with a special emphasis on potentials for its development in the area of AP Vojvodina in the Republic of Serbia. Special attention is given to presentation of local resources (natural, social, etc.) that are suitable for development food tourism. Also, the paper work points out the importance of tourism events that contribute to the popularization of local culinary specialties, i.e. manifestations that take place in honor of food in rural areas, which can and /or already represent the basis for development food tourism. Authors give emphasis in research for possibilities for complementary development different types of tourism based on food which is characteristic for the area of AP Vojvodina and special attention are given on rural tourism development. On that way article showes some guidelines for future development of food tourism in target area. If tourism would be linking with agricultural production, ie. food that is characteristic for the region of AP Vojvodina, a new quality of image of tourist destination would be obtained. Through linking tourism, agriculture, events, food trade, can be start up development of rural areas of AP Vojvodina and it can be one of the possible ways how to slove numerous problems that burdning rural areas of this region nowadays.
\end{abstract}

Key words: food, tourism, agriculture, destination, rual area, event, market

JEL classification: M31, M37, Q13.

\section{ПОТЕНЦИЈАЛИ ЗА РАЗВОЈ ТУРИЗМА ХРАНЕ У АП ВОЈВОДИНИ У РЕПУБЛИЦИ СРБИЈИ}

\begin{abstract}
Апстракт

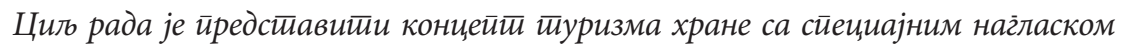
на йоиенцијале юеговогі развоја у йодручју АП Војводине у Рейублиии Србији. Посебна йжна иосвећена је ирредсииавльюну локалних ресурса (ириродних,

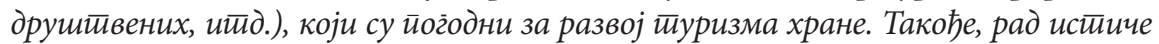

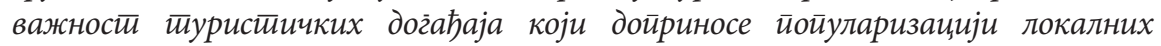
кулинарских сиеиијалитетй, ијј. манифесииација које се одржавају у части хране

\footnotetext{
${ }^{1}$ e-mail: predrag_v@iep.bg.ac.rs, ORCID ID https://orcid.org/0000-0002-4723-9815

${ }^{2}$ e-mail: marija.mosurovic@pupin.rs, ORCID ID https://orcid.org/0000-0002-7471-4933

${ }^{3}$ Article as research is financed by the Ministry of Education, Science and Tehnological Development of the Republic of Serbia.
} 
у руралним срединама, а које могу и / или већ иредстиавтају основу за развој

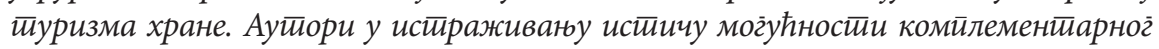
развоја различитих врсииа ииуризма на основу хране која је каракиетистична за йодручје АП Војводине, а йосебна йажюа се йосвећује развоју руралног йуризма. На йај начин рад ирриказује неке од смернииа за будући развој ирехрамбеног ииуризма у иильном йодручју. Ако би се ииуризам йовезивао са йолойривредном ироизводюом, ијј. храном која је каракиееристична за иоодучје Војводине, добио

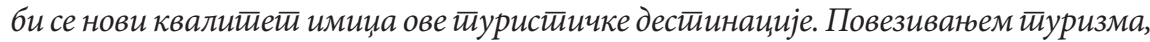
йовоиривреде, догађаја, йрговине храном може се йокренуйи развој руралних йодручја у АП Војводини, а йо може биии један од начина да се реше бројни ироблеми који данас ойиерећују рурална йодручја.

Клучне речи: храна, йуризам, йољойривреда, десиичначиј, рурално йодручје

\section{Introduction}

Tourism has become a phenomenon that has entered all segments of economic and social life. Nowadays, there is practically no country in the world that does not invest into tourism development, expecting positive outcomes of such investments. The great numbers of possibilities of how to put the existing resources (natural, social, anthropogenic, etc.) into the function of tourism development are being explored, with the aim to improve the tourist offer. The challenges caused by the modern environment undoubtedly have implications on abandonment of the traditional understanding of the tourist destination towards its understanding not only as a destination product but also as a destination experience and a transition from destination marketing to destination management (Pestek, A. \& Nikolić, A. 2008). The rapid expansion of interest in professional literature on food tourism has been practically recorded since 2008 (Ellis, $A$. at al., 2018). This increased prominence is demonstrated through a series of recent special issues of tourism academic journals and numerous of major international conferences exploring food tourism. In the Republic of Serbia, there are respectable conditions for the development of all the aforementioned types of tourism (food tourism, manifestation/ events, rural tourism, etc.). One of the areas that pose favourable conditions for the food tourism development is the Vojvodina region.

\section{Literature Review}

Rural tourism is not based on stimulating mass arrivals, but focuses on a targeted "exclusive" market that needs a holiday that offers "something different, different and specific" (Tyrväinen, L. at al. 2001). Because experiences are deeply personal, 'tourists constitute an unmanageable group of consumers, and their experiences are inevitably different even though they may consume the same tourism product'. This is an important reason why more recent studies have tended to focus on how experiences are constructed or managed rather than individual tourist experiences themselves. One of the thematic types of tourism, with growing interest in recent years, is the food tourism. 
Food has a particularly important role in the development of tourism services, since it makes up a large part of tourism expenditure and it is a necessity, for all tourists, in all destinations. (Richards, G. 2012, p.2-3). Hjalager, A. M., and Richards, G. (2002) supports this by stating local food is an essential part of the tourism experience since it can serve both as a cultural and an entertaining activity. In the sense of creating a destination image via locality of food; considered as an important factor of a national cultural identity and destination promotion (McKercher, Okumus \& Okumus, 2008). Wolf, E. (2002,) describes food tourism as simply - "travel in order to search for, and enjoy, prepared food and drink." This definition can also include a dinner in the house of a local, a visit to the local market, or attending a local food event, etc. This concept can be very broad. In the Master plan of sustainable development of rural tourism in Serbia (2011), food tourism is defined as type of tourism whose the main motive is taste and consummation of food and wine on local, national, international, traditional and autochthonous levels. It covers the experience of gastronomy related to culinary heritage. Includes agricultural products such as alcoholic beverages, such as brandy. The relationship between food and tourism presents significant opportunities for sustainable rural development; in particular, linking the two can create jobs and increase sales of local produce, as well as create interrelationships, linkages and networks between stakeholders (Hall, C. M. at al, 2003).

Food is now recognized as one of the fastest growing aspects of tourism today. Studies reveal the role of food as both a lifestyle marker and a means of cultural identification. When consuming food of 'others', tourists can become 'part' of that culture, however briefly. Food also provides 'authentic' representation of the culture for the tourist. Tourism literature reveals the potential role for food in tourism in sustaining regional identity and contributing to regional development, as well as being a key element in competitive destination marketing (Steinmetz, R., 2010). Local food can be seen as a mean to explore a country's culture, because represent the geography, history, and people of a country. It represents the identity of a destination, like a symbol of a place. Hence, the importance of linking food as promotion tool in tourism. (Reza, A., 2014). In relation to rural tourism, food culture is widely seen as an avenue for making small businesses more economically and socially self-sufficient through increasing tourist spending, extending the tourist season and enhancing local identity (Everett and Aitchison, 2008, Hall, 2005). Evidence from literature has shown that the slow food agenda is not to completely rid of fast food but it is a noble attempt to change our eating habits so that the taste, our cultural beliefs and identity are not homogenized by a global food culture devoid of diversity and pleasure (Donati, K., 2005). Accommodation on rural tourist farms creates a specific rural experience with its uniqueness, which makes it different from the accommodation offer characteristic of traditional accommodation (hotels, hostels, guesthouses, etc.). The accommodation and stay of tourists on farms is in line with the rural environment and culture of the local community. Consumer loyalty is strongly conditioned by the quality of services offered to enable tourists to participate in the lifestyle of the local community, or the host they reside with (Albacete-Sa'ez, C., at al. 2007). Re-arrival and income generation depend on how tourists evaluate the quality of services during their first stay, and accommodation and food are the basic elements of the offer that tourists evaluate when they deciding whether to stay in a destination or in a rural tourist household. If they are provided with high quality of services, that is, if their tourism experience is positive, the chances for their re-arrival, but also the generation of new tourists, increase, which 
creates conditions for growth of income and competitiveness of that tourist destination. (Tian-Cole, S., and Crompton, J. 2003; Tian-Cole, S., at al. 2002; Kozak, M. 2001).

Hjajager and Corigliano (2000, p. 282) identify that food images are used in marketing in the following ways:

- Complementary - Food is used as appealing eye-catchers in brochures, videos and television programmes;

- Inventory - 'An intensive effort is being put into creating new tourist products and experiences. The inventory regions may create a special atmosphere that appeals to guests whose main interest is the culture of food and eating;

- Superficial - Where food is used as a side 'prop' but is not considered the focus of the images portrayed.

Determining different needs of various tourist segments would create a better design of local food products (Sengel, T, at al 2015).

In defining factors affecting local food consumption, Mak et al. (2012) reports five dimensions; cultural and religious factors, socio-demographic factors, motivational factors, personality and past experience. Sengel, T, et al. (2015) highlights three:

1) Demographic factors were discussed as important affecting tourist food consumption and commonly include indicators such as age, gender, education level, marital status, religious belief and so on. (Kim S. et al., 2003).

2) Motivational Factors - Eating is a basic need of human nature, every tourist eats local food when travelling away from home. Taste, looks, scent of the food and the authenticity of the place are sensory issues perceived by five senses and can be considered as physical motivators (Fields, K. 2002). Related to this idea Kim et al. (2009) mentioned taste, flavor, smell and visual image of food as physical motivators that reflects sensory appeal as well. Besides representation of the restaurant, decoration, music, lighting and architecture are accepted as aspects of physical environment (Yuksel, A. \& Yuksel, F. 2003; Meiselman, H. L. at al. 2000). Travelling is seen as a way of escaping from routine (Smith, S. 1994), so the tourists prefer eating in authentic places with traditional atmosphere instead of worldwide food chain restaurants. Eating local food in local restaurants is also accepted to be a way of social and cultural interaction since it gives clues about local way of living, manners, geography, economy and related cues (Getz, D. 2000).

3) Psychological Factors - Apart from given motivational and demographic factors some psychological factors based on personal characteristics, past exposure, variety seeking is also reported to affect local food consumption in destinations. Mainly food neophobia and neophilia have been examined by authors. While explaining these terms, people may naturally dislike or be dubious to taste unfamiliar food (neophobia), on the other hand they also have a curiosity to taste local food (neophibilic) (Fischler, 1988). Related to this, willingness of consuming new food and being interested in trying unfamiliar food are mentioned to be push factors for some tourists to try local food at destinations (Chang, Kivela, Mak, 2011). 


\section{Materials and methods}

This paper work aimed at perceiving the potentials for food tourism development in AP Vojvodina regarding potentials (natural, social etc.) that this region of the Republic of Serbia posess. The research is based desk research based on the analysis of exsisting literature, actual documents, developing strategies, studies as well as the international documents, which were adopted for this area and all other relevant sources that served as a basis for research through copmparative analysis. Main hipotes of article is that AP Vojvodina posesses favorable condition for develop food tourism. Particularly authors were discussed about complementary development of food tourism with cocncept of "slow food", organic food, rural touirsm, tourism of events, organic food, etc. Authors suggest brending food as way to preserve authohtonity of local food delicates. This could be one of the element of tourist supply that can attract tourist to visit this area.

\section{Discusion and results}

\section{a) Characteristic of rural areas in Vojvodina and possibilities for development tourism with special turn to possibilities for development food tourism}

In AP Vojvodina there are a total of 465 settlements, of which 415 are rural settlements. The population structure in AP Vojvodina based on the last two Censuses with the number of rural households is shown in Table 1.

Table 1. Total population, households and average number of household members according to the 2002 and 2011 Census by districts in AP Vojvodina.

\begin{tabular}{|l|c|c|c|c|c|c|}
\hline \multirow{2}{*}{$\begin{array}{c}\text { District in AP } \\
\text { Vojvodina }\end{array}$} & \multicolumn{2}{c|}{$\begin{array}{c}\text { Total } \\
\text { population }\end{array}$} & \multicolumn{2}{c|}{ Total number of households } & \multicolumn{2}{c|}{$\begin{array}{c}\text { Average number members } \\
\text { of households }\end{array}$} \\
\cline { 2 - 7 } & 2002 & 2011 & 2002 & 2011 & 2002 & 2011 \\
\hline Severnobački & 200.140 & 185.552 & 74.359 & 70.939 & 2,69 & 2,62 \\
\hline Zapadnobački & 214.011 & 187.581 & 74.627 & 69.366 & 2,88 & 2,70 \\
\hline Južnobački & 593.666 & 607.835 & 207.848 & 222.164 & 2,86 & 2,73 \\
\hline Severnobanatski & 165.881 & 146.690 & 61.396 & 57.127 & 2,70 & 2,69 \\
\hline Srednjebanatski & 208.465 & 186.851 & 73.917 & 69.362 & 2,82 & 2,57 \\
\hline Južnobanatski & 313.937 & 291.327 & 106.588 & 102.494 & 2,94 & 2,84 \\
\hline Sremski & 335.901 & 311.053 & 111.222 & 105.985 & 3,02 & 2,93 \\
\hline
\end{tabular}

Source: Statistical Office of the Republic of Serbia, Census Books Nos. 003 and 019 (2011 and 2002)

With about $12 \%$ of people aged 65 and over, or about $20 \%$ of people over 60 , Vojvodina is in an advanced phase of demographic aging (Pejanović, R. 2010). The contingent of the young population was reduced from $30 \%$ in 1971 to $22.6 \%$ in 2002 , or $21.5 \%$ in 2008, while the aging index in 2008 was 99.7 (Regional Spatial Plan AP Vojvodina, 2011).

According to the 2011 Census, the share of the population without school qualifications and incomplete primary education was almost double in rural than in urban areas. It 
is assumed that the reason for this population structure is the oldest age group, which predominantly lives in rural areas of Vojvodina and that the high specific mortality rate of the oldest population is the cause of this phenomenon (Sokolovska, V. and Žolt, L. 2013). At the same time, the percentage of rural population with a college or university degree $(6.71 \%)$ is almost three times lower than in urban areas (19.13\%) (Rodić, V. et al., 2013). These data are important because human resources are a basic prerequisite and basis in providing quality tourism services. The quality of services depends on their availability and care. It is the quality of services that is the basic factor for creating loyal consumers and therefore long-term competitiveness (Basiony, A. E. at al. 2014). In the structure of GDP of AP Vojvodina, industry participates with $53.4 \%$, services with $30 \%$, agriculture with about $10 \%$, and construction with $6.9 \%$, while GDP per capita in rural areas is $74 \%$ of the national average. In rural areas, agriculture continues to be a major economic activity and a major source of income. However, agriculture is characterized by low productivity and competitiveness, a high level of extensive production with low incomes per household. In addition to the low income of agricultural producers, foreign direct investment in agriculture is below $1 \%$ of total investment. Consumer purchasing power is also extremely low (Andrić, N., at al. 2010). The main characteristic of rural households in terms of ownership structure is that they are small and divided. Such a structure has a negative impact on agricultural production. Because of all this, there is a need for an additional source of income. The development of rural tourism is one option. There are natural predispositions to such development but not well-designed social activities. For example, out of 415 rural settlements in AP Vojvodina, only 17 developed partially rural tourism (Jelić et al., 2010; Andrić, N. at al. 2010). This lack must necessarily be reversed in the context of the evidently present potentials for tourism development. This is also in line with the concept of multifunctional agriculture that has been promoted by the EU since the 1990s. During the 1990s, the EU promoted the "Multifunctional concept of agriculture and rural development" as part of its Common Agricultural Policy program, wellknown as acronym the CAP, which emphasized, among other things, the need for development of rural tourism. In formulating the multifunctional concept in the development of European agriculture, it has been starting from recommendations which gave the Food Agriculture Organization, the Agenda 21 document (Chapter XIV), as well as numerous international documents and research, etc., have started.

Agriculture as a primary state industry has far-reaching interests for complementary cooperation with all sectors of the economy, including tourism. Vojvodina with its food production resources represents a great opportunity for the development of food tourism. This attitude is supported by the following facts:

- Agricultural industry is highly developed in Vojvodina. It is those different agricultural products that could be seen as the basis for enriching the tourist offer of the local tourist destinations and could represent the basis for attracting tourists whose visit to certain destinations is primarily motivated by food consumption;

- There is a large number of different events throughout Vojvodina focused on local agricultural products and traditionally prepared food. Almost every village has a specific manifestation dedicated to some agro-food product and / or culinary product or specialties. These activities make the local tourist offer more attractive, which leads to complementarity in the development 
of different types of tourism, such as food tourism, manifestation tourism (tourism events), rural tourism, etc.

- The relatively well preserved natural environment is also favourable in terms of the production of organic healthy food, which represents a trend for tourists from highly urbanized centers, nowadays. Even more, this area can offer the concept of "Slow food tourism" versus "Fast food tourism", characteristic for very urbanized city centers. That way the local tourist offer can be further enriched.

- In AP Vojvodina, there are more than 30 nations and nationalities that have rich anthropogenic heritage. Each area/village has its own local gastronomic specialties that could potentially become the object of tourist offer and represent the distinction in relation to tourism offer of other local rural tourist destinations.

If all the aforementioned activities are properly designed in terms of marketing and management, it can help create a large number of different tourist products that could improve tourism offer not only in Vojvodina, but also in Serbia in general.

\section{b) Possible directions for the development food tourism in the area of AP Vojvodina}

Appropriate trends have been observed in the area of rendering services of food and drink in recent years. The system of classic restaurants, which until recently was predominantly present, is changing. Tendencies in the tourist market in addition to the already existing cafe restaurants and fast food restaurants, there are also catering establishments where one can consume organically produced healthy food, as well as the sale, promotion and consumption of food at different events and at different events. In this direction, the future directions and perspectives for develop food tourism in AP Vojvodina should be seen.

1) The concept of „slow food“ - The Slow Food movement started in Italy in 1986 with the work of Carlo Petrini. This was followed by the activities of some intellectuals in Rome who decided to serve the locals and tourists alike the traditional Italian food as an alternative to mass-produced food worldwide. These efforts were encouraged and today it has over 100,000 members in about 130 countries (Petrini, C. 2001, cited in Nilsson et al., 2011). According to Petrini, "Slow food unites the pleasure of food with responsibility, sustainability and harmony with nature”. The Slow Food Movement's beliefs led to a new concept of eco-gastronomy. This new thinking is based on the premise that everyone has a fundamental right to enjoyment or pleasure and that the plate and the (world) planet (3Ps) are interrelated (Tam, D., 2008; Folorunso, S. et. al. 2013). Slow Food Serbia is a nonprofit organization established in 1989 in response to new lifestyles that have brought fast food. Slow food indicates that local food is disappearing all over the world. Therefore, the goal of organization is to raise people's awareness of the importance of food, that it is important for us to know what we eat, where our food comes from, how we prepare and produce it. Slow food believes that every person should take responsibility and protect the local gastronomic heritage and products that threaten to disappear (Slow food Serbia, 2019). The primary goal of the slow food organization is to protect indigenous biodiversity through the biodiversity foundation, which means the diversity of plant and animal breeds. The best example for Serbia is the isolation of "Karakačna sheep", "pig 
mangulica", "cow bušara", as well as a variety of authentic plant varieties such as beans "Poljak" and "Smiljan", etc. Slow food has three main tools for research, maintenance and protection of biodiversity. One of them is the "Ark of Taste". It is a catalog of disappearing food that is part of the culture and tradition of Serbia and the whole world. (Slow food Serbia, 2019). In May 2019, the publication “The Ark of Taste of Vojvodina” was presented. The aim of this publication is to unite the gastronomic, cultural and tourist offer in AP Vojvodina in one place. The publication is a kind of guide through the various regions of Vojvodina and their food offerings. The publication was created as a result of the work of the Scientific Institute for Food Technologies from Novi Sad, DDOR Insurance Novi Sad and Slow food organization. The publication presents all kinds of food that can be offer to turists such as fruits and vegetables, pasta, bakery products, dairy products, meat products, honey, as well as all other traditional dishes and beverages in this area. In other words, the publication presents the gastronomic wealth of AP Vojvodina, which bears historical and cultural specifics.

2) Organic food - The modern trends in the tourism market move further from the concept of mass tourism offered by vacations in destinations located on the seashore and/or mountain ski resorts. There is striving towards activating all segments of tourist demand in order to achieve the best results in tourism development. In this way the countries, i.e. destinations that do not possess the resource bases for developing the socalled "mass tourism" seek their chance on the tourism market by offering alternative tourism products. (Vuković . P. at al. 2015.). Modern tourists who go to rural destinations want to completely consume so-called "rural tourism experience". In that sense, they want to escape from the modern way of life which one of the most recognized characteristic is „fast food“. Modern tourists who spend their vocation in rural tourist destination want to eat „slow food“, or beter word food made by organically produced agricultural products. Rural tourist destinations that can offer such more organic products are more competitive. (Vuković, P \& Roljević, S. 2018). Organic farming is a fully controlled production. IOFAM Organic international (2019) define organic agriculture as "production system that sustains the health of soils, ecosystems and people. It relies on ecological processes, biodiversity and cycles adapted to local conditions, rather than the use of inputs with adverse effects. Organic Agriculture combines tradition, innovation and science to benefit the shared environment and promote fair relationships and a good quality of life for all involved" (IOFAM, 2019). Based on IFOAM rules, production conditions must be adapted to the conditions specific to each country or area where organic farming takes place, and also to be regulated by law. Therefore, the area on which organic farming is based must precisely meet the defined conditions. This includes isolation of land parcels, livestock farms and processing capacities from possible sources of pollution, then irrigation water of appropriate quality, harmonized development of crop and livestock production and qualification of experts and producers for organic agriculture, with obligatory continuous innovation of knowledge. It can be said that the consumption of organic food is as old as humanity is, but humans have led to the fact that today, due to economic development, most of the food contains harmful substances. Since most diseases originate from irregular and contaminated food as well as improper nutrition, the advantage of branch agriculture over conventional agriculture lies precisely in the production of health-safe food. Another very important benefit is the conservation of the environment by conserving its resources - land, water and air. (Kljajić. $N$. at al. 2008). Organic farming and rural tourism have multiple complementarities in development, which is reflected in the following: 
- Sustainability of organic agriculture and rural tourism is based on the rational use of natural resources. The intention is to preserve and increase their diversity with minimum negative impacts on the environment.

- Organically produced agricultural products are subject to inspection and control, hence the trust of tourists who come to rural destinations that they will exactly be able to consume these organic products, which increase revenues of producers, as well as farmers who offer tourist services.

- Rural tourism is, by definition, small-scale and low intensity. As such it is found to comply with the organic products which, according to numerous studies have shown give lower yield of crops in comparison with conventional agriculture. However, these yields can be compensate with numerous benefits that organic farming offer, such as, for example, increased soil fertility, reduced pollution, conservation of agro-eco system, income security, strengthening communities, improving the health of the population, etc.

Rural tourism and organic agriculture are complementary activities. Both are low intensity and small volume. This is because they put the environment in the forefront. As one of the possibilities that would contribute to the development of both organic agriculture and rural tourism, it is possible to connect them in a tourist offer. In this way, the boarding house offer will be enriched and made possible by the creation of a large number of different specialties from organically produced agricultural products. The expectations are that in this way specific tourism products based on food tourism could be formed, which in a number of ways could enrich the overall tourist offer - from the classical boarding house to tourism events that would attract a certain number of tourists to rural areas. By doing so, rural tourism destinations that would connect these two complementary activities would also become more attractive to the market, ie. more competitive in relation to those destinations that do not have this kind of tourist supply.

In Serbia has done pretty small on linking rural tourism and food tourism with organic farming so far. It can be said that these are sporadic attempts. Considering the potentials that exist for the development of rural tourism, as well as organic agriculture, it is justified to expect some strategic approach at the state level. It provides opportunities for developing specific tourist brands for destinations that are located in characteristic natural sites. Especially if we understand the geographical diversity that the country has and which provides opportunities for the development of various types of organic farming production. It is also a possibility for development of tourist competitiveness of Serbia, which offers various rural tourism products. The range of tourist offer spreads both on-board and extra-board a tourist offer (Vuković, P and Roljević S. 2018). Having in mind all the foregoing, it is reasonable to expect appropriate activities to make link between organic agriculture and rural tourism. The results that could be achieved would be in favor of development and rural tourism and organic agriculture. This is in line with general market trends that show growth in demand for both types of business.

3) Tourism of events - Hall and Mitchell (2001) defined food tourism as "visitation to primary and secondary food producers, food festivals, restaurants and specific locations for which food tasting and/ or experiencing the attributes of specialist food production regions are the primary factor for travel". It should be noted that every visit to a local food seller or cafe' is not food tourism; but a deliberate effort on the part of tourists or individuals to experience a 
food event or taste a particular type of food as the case may be. Every tourist destination tries to develop its own tourist product that is unique and identifiable to that destination. One such tourism product is a food event (Folorunso, S. et. al. 2013).

Hall et al. (2003) mentioned that travel behavior or tourist decision in travelling to participate in any food event should be primarily motivated by the desire to have a different experience. Food and its associated events can become part of a destination attraction and could be utilized as a tool to create desire in tourists to experience rural tourism. The above discussion points to food being an important motivating factor for tourists to visit a destination in their quest for a satisfying experience .Each rural area has some natural specificity that affects the agricultural production and the food consumed therein. For this reason, there are a large number of different culinary specialties that can be found in different tourist destinations.

In the AP Vojvodina live 28 nationalities with rich anthropogenic heritage with many different amenities and different manifestations dedicate to food. Tourist organization of AP Vojvdina each year makes publications in which promote events/ manifestations dedicate to food. In September 2019 there were 21 events dedicate to food on area of AP Vojvodina according to Tourist organization of Serbia and Tourist organization of Vojovodina in 2019. It is important to mention that this table included different events which promote food by Tourist organization of Serbia but in practice calendar of food events is richer, because each village in AP Vojvodina has its own manifestation dedicate to some of local food (agricultural) products. "The Catalog of events" was published in 2018 by Tourist organization of Serbia in which was presented all tourist events and manifestation on the territory of Serbia. According to this source in AP Vojvodina in 2018 held more than 100 different events dedicate to food.

\section{c) Branding of agricultural food products and appropriate marketing strategies for autochthonous agricultural food products}

In today's market conditions, there is a lack of healthy, traditional, local agricultural products, which made demand and price increase due to their rarity and importance for consumers. Branded agricultural products guarantee to meet the sophisticated customer's needs, and they are often the reason for journey (Djordjević, T. at al. 2014). In today's market conditions with frequent and strong fluctuations, the brand plays an important role. The brand also plays a large role in the food market because of its high purchasing frequency, as it guarantees appropriate quality and variety from other similar products. Often, generic product names are given adjectives that indicate Geographical Indication or Appellation of Origin. This is done in order to differentiate the product and create a comparative advantage in the market.(Giovannucci, D., at al. 2009). According to legal law regulations in the Republic of Serbia, two types of designations are protected under the geographical origin: name of origin and geographical indication. The name protects the name of the location/destination from which the product originates (village, region, country, etc.), and the geographical indication identifies that the particular product originates from the appropriate geographical territory (village, region, country, etc.). These products are of great importance for tourism development, because the product and the territory share a reputation, so the success of the product often leads to strengthening the attractiveness of the area and is related to the benefits that can be achieved through tourism (Djordjević, T. at al 2014). Adding value to products strengthens 
the territorial capacity of the area, improves the image of the territory and local identity of the population, while through networks and cooperation based on placement to a given value, increases employment and strengthens social cohesion. This value-added product and product placement process includes the SME sector, farm production, support from local development actors and institutions. It strengthens the presence of consumers and tourists in the appropriate destination by offering local products and services created using lolal resources (Živkov, G. i sar. 2013).

Depending on the region or local environment where the production takes place, the products have different characteristics. On the basis of added value in the market, they achieve a higher price, while consumers are satisfied with their consumption. Some authohtonious products in the area of AP Vojvodina are more or less known and have different representation in the diet of consumers. In order to increase the demand for these products, even though they currently exist, it is necessary to protect the authenticity of the products, of exceptional value, to legalize production and to carry out the necessary veterinary-health surveillance and to achieve as much standardization as possible, especially meat products (Puškarić, A. at al. 2013).

It is important to state that producers of autochthonous agricultural food products of the area of AP Vojvodina should face competition in the target market, that is, other manufacturers of the same and similar indigenous products. Competitive products can be products of other manufacturers of indigenous products, but also products that come from industrial production. It is industrial food products that can replace traditional products, and the most common trump card is low prices. For this reason, it is necessary to position the products of a certain area in the target market with a predetermined strategy of appearance, which will include emphasizing the advantages of specific products and a specific geographical area, as well as the benefits obtained by their consumption. It is important that the development strategy also envisages linking of authohtonous agricultural products with the area in which the production takes place, emphasizing both the benefits of the products and the important characteristics that characterize the area, such as the untouched nature, the richness of the indigenous species, local plants and animals traditionally used in nutrition and the like. In order to present a range of indigenous agricultural food products in a particular geographical area, it is important that the packaging is adapted to identify the origin of the product immediately. The packaging should be of a modern design, however, the materials used in the packaging should be made exclusively of natural materials such as wood, jute, linen, etc. The marking should be in accordance with the concept of presenting the offer of agricultural food products of a particular locality. The authohtonous food product of a particular area should be of uniform and unique quality, that is, the product of different manufacturers should have the same quality, while the parts of organo-leptic properties should represent the details on which the products are differentiated. In order to reduce uncertainty and possible suspicion of potential customers of the product, efforts should be made to find a way to actualize the specificity of the taste by searching for material indicators of the quality of the product. Protecting the geographical origin of products is an important part of the EU's Stabilization and Association Agreement, which applies to agriculture and the food industry. The EU expects Serbia to protect its original products and register them according to group rules.Many EU Member States are working to create the conditions to protect specificities in the agricultural and food industries by a method commonly 
known as geographical origin. Protecting the geographical indication is a very useful tool for the development of the region, especially in rural areas, and represents an opportunity for Serbian producers of traditional products to use their branding to somehow brand their product and thus increase competitiveness (higher sales price, market recognition). (Paraušić, V. at al. 2007).

\section{Conclusion}

Today, tourism has undergone lot of changes, both on the sides of tourist demend and supply. The concept of mass tourism minimizes the contacts of tourists with the local community and residents. The new approach to tourism development is more flexible, marketsegmented and oriented towards residents of local tourist destinations. Also, the new approach to tourism is more concerned about the environment of a tourist destination. Modern tourists have greater and different requirements. Tourist travel nowadays because they want to live new tourist experience, different than traditional tourism offer. One of the experiences that make modern tourists to travel is the possibility of tasting the new gastronomic (food) flavors. Rural tourism is related to food tourism. Tourists that visit rural areas are motivated to consume local agri-food products as well as various gastronomic specialties made from local food. Rural tourism is of low intensity and low scope. It is addressed to the individual preferences of tourists who preferably visit rural areas. This concept of rural tourism is in the line with the concept of food tourism, to meet tourists as a consumer, enabling them to enjoy in the flavors of food, which is the primary motive for their journey. AP Vojvodina possesses the great potential for development of both types of tourism - gastronomic and rural. More than $85 \%$ of the AP Vojvodina territory cover rural areas where $43 \%$ of the population lives. This data show the great potential for rural tourism development. Vojvodina is also characterized by the fact that there are more than 30 different nations with rich anthropogenic heritage. In Vojvodina there are 415 rural settlements and each village has its own manifestation/ event dedicated to local agricultural food products and food. There is also a well-preserved a natural environment that favors organic food in Vojvodina. Also, there is a well-developed agricultural industry. All this facts creates a good basis for the development of food tourism. In AP Vojvodina, there are a number of different factors that can attract tourists to stay in there. There are lot of resources that must be put into the function of tourism development. In accordance with the existing potentials of Vojvodina, Republic of Serbia, four directions and perspectives for the food tourism development are imposed: 1) the approach and concept of "slow food" tourism, 2) organic food, 3) event tourism and 4) branding of local agri-food products. An appropriate marketing strategy for local indigenous agri-food products should play an important role. It is important to have a distinction, to be differentiated and positioned in the market in order to respond to different demands of consumers / tourists, i.e. market segments. In this respect, it is important to apply a market focus strategy to the relevant market targets or niches. It is expected that this approach would have greater effects than the current undifferentiated marketing strategy, which did not produce major effects in tourism development.With the aim of interest of tourism development and the economy as a whole to strive to develop the marketing of indigenous products. Also, better communication among all stakeholders in the tourism market is needed in order to effectively meet the needs of tourist demand. In order to increase the tourist recognition of local products, it is necessary to 
brand the appropriate agri-food products. This is important in order to strengthen the image of Vojvodina, republic of Serbia as a tourist destination. In order to better market positioning, all the factors in the tourism supply chain need to be linked. This increases the conditions for stronger market competitiveness. The suggestion is that this connectivity be modeled on a cluster princip that is organized on a functional principle.

\section{References}

Albacete-Sa'ez, C., Fuentes-Fuentes, M. M. and Llore'ns-Montes, F. J. (2007). Service quality measurement in rural accommodation, Annals of Tourism Research, Vol 34, No.1, pp.45-65.

Andrić, N., Tomić, D., Tomić, G. (2010). Status and perspectives of development of rural tourism in the autonomous province of Vojvodina. In: L., Junancic, ed. Proceedings of the $118^{\text {th }}$ EAAE Seminar, Rural development: governance, policy design and delivery. Ljubljana: Biotechnical Faculty, Zootechnical Department, Book of proceedings, pp. 611-621.

Basiony, A. E. and Ghada A. A. (2014). Evaluating Tourism Service Quality Provided to the European Tourist - Applied on the British Tourist, MPRA Paper, No.57164, posted 9, July 2014, on-line: http://mpra.ub.uni-muenchen.de/57164/;

Chang, R.C.Y., Kivela, J., Mak, A.H.N. (2011). Attributes that influence the evaluation of travel dining experience: when East meets West. Tourism Management, 32, pp307-316.

Djordjevic, T., Ilić, D., Conić, M., and Stamenković, P. (2014), Branded food as potential for tourism development, journal: BizInfo, No.1, pp. 55-69.

Donati, K. (2005). The pleasure of diversity in slow food's ethics of taste, Food Culture and Society, Vol. 8 No. 2, pp. 228-242.

Ellis, A., Park, E, Kim, S, Yeomanb, I (2018). What is food tourism?, journal: Tourism Management 68, pp.250-263.

Everett, S. and Aitchison, C. (2008). The role of food tourism in sustaining regional identity: a case study of Cornwall, South West England, Journal of Sustainable Tourism, Vol. 16, No. 2, pp.150-167.

Fields, K. (2002). Demand for gastronomy product: motivational factors. In Hjalager, A. Richards, G. (eds.), Tourism and Gastronomy. London: Routledge, pp.37-50.

Fischler, C. (1988). Food, Self and Identity. Social Science Information, 27, pp.275-292.

Folorunso, S., Adeyinka-Ojo \& Khoo-Lattimore, C. (2013). Slow food events as a high yield strategy for rural tourism destinations, journal: Worldwide Hospitality and Tourism Themes, Vol. 5. No.4, 2013, pp.353-364.

Getz, D. (2000). Explore Wine Tourism: Management, Development and Destinations. New York: Cognizant Development Corporation.

Giovannucci D., Josling T, Kerr W, O’ Connor B, Yeung M. T. (2009). Guide to geographical indications-linking products and their origins. International trade centre. 
Hall, C. M., \& Sharples, L. (2003), The Consumption of experiences or the experience of consumption: An introduction to the tourism of taste. In C. M. Hall, L. Sharples, R. Mitchell, N. Macionis \& B. Cambourne (Eds.), Food tourism around the world: Devel-opment, management and markets (pp. 1-25). London: ButterworthHeinemann.

Hall, C.M. (2005). Gastronomic tourism - comparing food wine experiences, in Novelli, B. (Ed.), Niche Tourism, Contemporary Issues, Trends and Cases, Elsevier Butterworth-Heinemann, Oxford, pp. 73-89.

Hall, C. M. and Mitchell, R. (2001). Wine and food tourism. In Douglas, N. and Derrett, R. (Eds), Special Interest Tourism, John Wiley and Sons, Brisbane, pp. 307-329.

Hall, C.M., Sharples, E., Mitchell, R., Macionis, N. and Cambourne, B. (2003), Food Tourism around the World: Development, Management and Markets, Butterworth Heinemann, Oxford.

Hjalager, A., \& Corigliano, M. A. 2000. Food for tourists - Determinants of an image. International Journal of Tourism Research, 2(4), 229-306.

Hjalager, A. M., Richards, G. (2002). Still undigested: research issues in tourism and gastronomy. In A.M. Hjalager, G. Richards (eds.), Tourism and Gastronomy. London: Routledge. http://sustainabledevelopment.un.org/content/documents/Agenda21.pdf (accessed 21.08.2019);

IOFAM, 2019 offical web: https://www.ifoam.bio/en/organic-landmarks/definitionorganic-agriculture. accessed: 17.08.2019.

Jelić, S., Gligić Dumonjić, J., Kuzman, B. (2010). Serbian family households in respect to rural tourism development. Economics of agriculture, International scientific meeting: Multifunctional agriculture and rural development (V), Belgrade, II Book, pp. 275-280.

Kim, S., Lee, C., Klenosky, B. (2003). The influence of push and pull factors at Korean national parks. Tourism Management, 24, pp.169-180.

Kim, Y.G., Eves, A., Scarles, C. (2009). Building a model of local food consumption on trips and holidays: a grounded theory approach. International Journal of Hospitality Management, 28, 423-431.

Kljajić N., Vuković, P. and Arsić, S. (2008). Organska poljoprivredna proizvodnja i uloga marketinga u njoj, časopis: Ekonomika poljoprivrede/the Economic of Agriculture, No.4, God/Vol. LV, No.4, pp.421-429.

Kozak, M. (2001). Repeaters' Behavior at Two Distinct Destinations. Annals of Tourism Research, Vol. 28, Issue 3, pp. 784-807;

Mak, A.H.N., Lumbers, M., Eves, A., Chang, R.C.Y. (2012). Factors influencing tourist food consumption. International Journal of Hospitality Management, 31, pp.928-936.

McKercher, B., Okumus, F., \& Okumus, B. (2008). Food tourism as a viable market segment: It's all how you cook the numbers!. Journal of Travel \& Tourism Marketing, 25(2), pp.137-148.

Meiselman, H. L., Johnson, J. L., Reeve, W., Crouch, J. E. (2000). Demonstrations of the influence of the eating environment on food acceptance. Appetite, 35, pp.231-237. 
Nilsson, J.H., Svard, A.C., Widarsson, A. and Wirell, T. (2011). Cittaslow' ecogastronomic heritage as a tool for destination development, Current Issues in Tourism, Vol. 14 No. 4, pp.373-386.

Paraušić, Vesna, Kuzman, B., Arsenijević, Ž. (2007). Sajamska promocija poljoprivredno-prehrambenih proizvoda iz Srbije. Međunarodni naučni skup: Multifunkcionalna poljoprivreda i ruralni razvoj (II) - očuvanje ruralnih vrednosti, tematski zbornik, knjiga I, Beograd-Beočin.

Pestek, Almir, and Aleksandra Nikolic (2011). Role of traditional food in tourist destination image building: example of the city of Mostar. UTMS Journal of Economics 2 (1): 89-100.

Pejanović, R. (2010). Demografski problemi kao ograničavajući faktori ruralnog razvoja AP Vojvodine. Glasnik Antropološkog društva Srbije, Vol. 45, str. 65-75.

Popis stanovništva 2011 godine, Republički Zavod za Statisiku Republike Srbije.

Puškarić, A., Vuković, P. and Rajnović, Lj. (2013). Turizam i proizvodnja i plasman tradicionalnih lokalnih proizvoda, pp.142-168. Monografija: Stanje i mogućnosti razvoja održive poljoprivrede i ruralnog razvoja u Podunavlju, Institute of Agricultural Ecomic, Belgrade, Serbia.

Regional Spatial Plan of AP Vojvodina, 2011.

Reza, A., (2014). The Role of local food in the touristic experience, A focus on Visit Tampere All Bright! Marketing Program, Tampere Universtiy Of Applied Sciences.

Richards G. (2012). Food and the tourism experience: major findings and policy orientations. In Dodd, D. (ed.) Food and the Tourism Experience. OECD, Paris, pp.13-46.

Rodić, V., Bošnjak, D., Janković, D., Karapandžin, J. (2013). Demographic characteristics of rural populations in Vojvodina as a factor of rural economy diversification. The Seminar Agriculture and Rural Development - Challenges of Transition and Integration Processes, Department of Agricultural Economics, Faculty of Agriculture, University of Belgrade, book of proceedings, pp. 112-123.

Sengel, T., Karagoz,A., Cetin, G., Istanbullu Dincer, F, Mugan Ertugral, S, Blank, M. (2015), Tourist Approach to local food, journal: Procedia - Social and Behavioral Sciences 195 (2015) pp.429 - 437.

Smith, S. L. J. (1994). The tourism product. Annals of Tourism Research, 21, pp.582-595.

Sokolovska, V., Žolt, L. (2013). Demografske promene stanovništva Vojvodine: Regioni i regionalizacija 2: sociološki aspekt (ur: Sokolovska, Marinković), str. 11-22. Novi Sad: Mediterran Publishing d.o.o.

Steinmetz, R. (2010), Food, Tourism and Destination Differentiation: The Case of Rotorua, New Zealand. Web. link: http://aut.researchgateway.ac.nz/bitstream/ handle/10292/1090/SteinmetzR.pdf?sequence=3

Tam, D. (2008), "Slow journeys, what does it mean to go slow?", Food Culture and Society, Vol. 11 No. 2, pp. 208-218.

The Catalog of events (2018), Tourist organization of Serbia. 
Tian-Cole, S., and Crompton, J. (2003): „A Conceptualization of the Relationships between Service Quality and Visitor Satisfaction, and their Links to Destination Selection". Leisure Studies Vol. 22. Issue 1.p. 65-80;

Tian-Cole, S., J. Crompton, and Willson, V. (2002). An Empirical Investigation of the Relationships between Service Quality, Satisfaction and Behavioral Intentions among Visitors to a Wildlife Refuge, Journal of Leisure Research, Vol. 34, No.1, pp.124 ;

Tyrväinen, L., Silvennoinen, H., Nousiainen, I. and Tahvanainen, L. (2001). Rural Tourism in Finland:Tourists' Expectation of Landscape and Environment. Scandinavian Journal of Hospitality and Tourism, 1:133-149.

Vuković P., Čavlin G. and Čavlin M. (2015), Complementarity in development of rural tourism with the development of thermal baths, spa and welness tourism, Economics of Agriculture/Ekonomika poljoprivrde, pp.259-270. Vol. LXII, No. 1 (1-284), 2015.

Vuković, P., Roljević-Nikolić, S. (2018). Chapter 9: „Partnership of Rural Tourism and Organic Farming to Achieve Goals of Green Economy: Rural Tourism and Organic Farming" pp. 210-232. Publisher: IGI Global - disseminator of knowledge; Organizational Culture and Behavioral Shifts in the Green Economy;

Wolf, E. (2002). Culinary tourism: A tasty economic proposition. Portland, Oregon: International Culinary Tourism Association. working paper No. 128. London: Overseas Development Institute.

Yüksel, A., \& Yüksel, F. (2003). Measurement of tourist satisfaction with restaurant services: A segment-based approach. Journal of Vacation Marketing, 9(1), 52-68.

Zakon o turizmu Republike Srbije (Сл. гл. 17/2019).

Živkov G., Tar D., Dulić Marković I., Marković A, Teofilović N., Raketić S., Bernardoni P. 2013. Dodati vrednost proizvodima REDD [pdf] web: http://www.eastagri. org/meetings/docs/meeting96/Background\%20Paper\%20SRB.pdf (accessed: 08.08.2019.)

\section{Internet soruces}

https://www.bastabalkana.com/2015/10/slow-food-srbija/ (Slow food Serbia, 2019, accessed: 21.08 .2019$)$

https://www.worldfoodtravel.org/cpages/what-is-food-tourism (accessed: 11.08.2019)

https://www.millionmetrics.com/food-tourism/ (accessed: 11.01.2020)

https://www.covingtontravel.com/2016/06/4-trends-food-tourism/ (accessed: 11.01.2020) 